\title{
Grundtvig, Anglo-Saxon Literature, and 'Ordets Kamp til Seier'
}

\author{
Af S.A.J. Bradley, York, England
}

"The first and greatest of Beowulf scholars, as everyone knows, was N.F.S. Grundtvig." So wrote Kemp Malone in 1941, and added, furthermore, "Of the many scholars who have followed Grundtvig in the field, none can compare with him in genius or in importance of achievement." ${ }^{1}$

Malone was partly motivated, no doubt, by the opportunity to reprove J.R.R. Tolkien - not yet the cult figure the Sixties were to make of him but the author of a lecture to the British Academy in 1936 which successfully appealed for a fresh literarycritical approach to the poem. This lecture, in Malone's view, was remarkable for catching up with Grundtvig, without the Oxford professor seeming to know of Grundtvig's existence, let alone what "everyone knows" - the supreme significance of Grundtvig's pioneering work. Tolkien on Beowulf, Malone suggested, was Grundtvig updated, even if, deplorably, Tolkien did not know it. And since it is roughly true to say that Beowulf literary scholarship since Tolkien's paper has largely followed Tolkien's lead, it could be said, with Malone, that Grundtvig, in a sense a century ahead of his time, has at last come into his own.

Professor Andreas Haarder has trenchantly taken issue with Malone's too-undiscriminating equation of Grundtvig with Tolkien. ${ }^{2}$ But there remains, notwithstanding any specific qualifications we should make, the widely agreed fact which warrants the attention of this project - the brilliance of the young Grundtvig's interpretation of the profounder meaning of the text Beowulf, not only unaided by any predecessor's work but, one might fairly say, half-impeded by the brave, but error-prone presentation of the only complete edition of the text itself, that of Grundtvig's fellowcountryman G.J. Thorkelin in 1815.

Various critics have tried to analyse the formula of Grundtvig's literary genius, often by listing the string of trade-labels one could attach to the name Grundtvig: "poet, preacher, theologian, statesman, educator, reformer, philologian" for example. ${ }^{3}$ In 
Grundtvig, as was not so in his contemporaries and immediate successors in Denmark or abroad, a rare range of qualifications and insights came together which, one might claim, happened to give him a rare degree of access into the Anglo-Saxon poet's own complex cultural preconditioning.

In this context, Professor Haarder's conclusion aptly endorses the desirability of a cross-disciplinary approach to the assessment of Grundtvig's achievement: "In engaging with Beowulf, Grundtvig was man of learning, literary critic, interpreter of myth, without it being possible to establish that in this work or that he is exclusively the one or the other... A treatment of the subject 'Grundtvig as Beowulf-critic' therefore seems necessarily to disrupt any strict pigeon-holing of the Grundtvig material."4

As far as scholarly criticism in English-language sources is concerned, there seem to be four well-established contexts of discussion of Grundtvig the Anglo-Saxonist: that of his contribution to the textual restoration and emendation of Beowulf; that of his discovery of the identity in history of Beowulf's king, Hygelac; that of his historic role as the first person to offer a literary-critical reading and interpretation of the whole poem of Beowulf; and that of his apparent anticipation of later twentiethcentury critical consensus on the poetic distinction and the serious and universal meaning of the poem Beowulf.

Just appreciation of the depth and extent of his response upon encountering the Anglo-Saxons has come slow and sparingly - as various scholars besides Malone have already said in print. Grundtvig was active in a range of Anglo-Saxon studies far wider than Beowulf alone. Over the years before and after his visit to England in 1830 he built up a collection of materials relating to all four major codices of Old English poetry and to individual poems from other manuscripts, as well as to a fair amount of Anglo-Saxon prose writing, based partly upon his own transcriptions from the manuscripts, partly upon the published works of other scholars - Junius, Hearne, Percy, Hickes, Wanley, Rawlinson, Ingram, Grimm, Coneybeare, Wright, Haliwell, Stephens, Thorpe, Kemble, and others - whose editorial readings, emendations, conjectures and interpretations he annotated and often countered with his own scholarly judgements. ${ }^{5}$ Furthermore, his influence on the rather sudden and swift development of Anglo-Saxon studies 
in nineteenth-century England and Germany, after so long an age of ignorance and neglect, was greater than generally appreciated, even if it did not always take the form Grundtvig himself desired. But above all, the intellectual complexity and the richness of Grundtvig's personal reception of Anglo-Saxon literature have been too little explored and evaluated, notwithstanding some notable achievements in this direction. ${ }^{6}$

Grundtvig has tended to be perceived by English-speaking scholars, even by those concerned to give him credit long overdue, as a satellite in the orbit of Beowulf. But a wider European evaluation of Grundtvig's achievements must needs perceive Anglo-Saxon literature including Beowulf as a satellite in the orbit of Grundtvig - a status which, incidentally, ought to stir in British scholars of the nineteen-nineties no such feelings of defensive chauvinism as were stirred by Grundtvig's activities in the eighteen-thirties, but rather to a sense of gratification over the unique and significant role which the oldest English literature has proved able to this extent to play in the shaping of modern European culture.

There is then a considerable number of important issues with which an English Anglo-Saxonist may be impressed when reflecting upon the work of Grundtvig and its context in the North-west European reception of Anglo-Saxon literature in the first half of the nineteenth century; and such issues an English Anglo-Saxonist would hope to see addressed in any major reevaluation of Grundtvig as Anglo-Saxonist.

There is, first, simply the remarkable phenomenon of Danish attention to Anglo-Saxon literature as part of a wider interest in ancient English literature in the early nineteenth century, reflected in Grundtvig's translations of extracts from Percy's Reliques, with a commentary in Danish - remarking on a variant of the Havelok legend - probably from the $1820 \mathrm{~s}^{7}$ In the absorption of all this, Grundtvig shows himself, as he does so often elsewhere, to be a remarkable synthesiser, conflating and harmonising neo-classical and romantic in idiosyncratic and distinctive manner. The saga of Grundtvig's involvement in AngloSaxon scholarship on both sides of the North Sea is incidentally an informative sketch of the broader affinities, visions, and impediments of an historical, cultural and political kind between 
England and Denmark in the nineteenth century. The patronage received by Thorkelin, Rask and Grundtvig from Count Bulow is an historical phenomenon intimately associated with the subject of Denmark's late eighteenth and nineteenth-century cultural relations with England: others involved with this project will doubtless give some attention to the social system represented by Bulow and the cultural and political implications of his remarkably enduring readiness to fund Anglo-Saxon research and publication in Denmark. Grundtvig talks about these things on various occasions, not least in his Prospectus, the Bibliotheca AngloSaxonica (1830), addressed to an English readership, ${ }^{8}$ and so does the English scholar Benjamin Thorpe who dedicated his 1855 edition of Beowulf to the memory of Bulow. ${ }^{9}$ The story of one single pioneer's combative involvement with Anglo-Saxon studies and controversy over almost half a century also merits a full and analytical description. Apart from its own remarkable and satisfying 'plot', in which, more or less, poetic justice is at length done, the narrative would be the record of a remarkable intellectual evolution which progresses in tandem with evolution in other areas of Grundtvig's life, public and private, intellectual and emotional; and which inevitably sheds much light on the intellectual, social, political and broadly cultural milieu in Denmark and its capital city over a period of extraordinary crisis and change. The story has often enough been sketched out, in evaluations from Grundtvig's lifetime onwards, in Scandinavia, America and England; the materials are diverse and relatively abundant - Grundtvig's own published writings and substantial notes and drafts in the Grundtvig Arkiv, in the Kongelige Bibliotek and elsewhere, even his annotations in books; the many public academic and quasi-academic responses to his work, in periodical literature, editions and translations; the records and minutes of such institutions as Grundtvig had dealings with; and more private responses, as in letters and diaries.

Worthy of fresh attention too is the phenomenon of Grundtvig as interpreter de novo, ab initio, ${ }^{10}$ of Beowulf, and of other Anglo-Saxon poetry; as anticipator of the twentieth century judgement - the subject of a number of papers over the last forty years. Establishing what Grundtvig really did believe - indeed what, in the fuller sense, he really said - of Beowulf and of the 
'Cædmonian' and other poems, as "konstværker" ["works of art"], involves the problem of defining Grundtvig's personal and often idiosyncratic values found in the kind of terminology which enters into his discussion of, for example, Beowulf: terms such as "smag" ["taste"], "epos" ["epic"] (in both of which terms we have to deal with the preconceptions of nineteenth-century neo-classicism), "ordet" ["the word"] (in which we have to deal with Grundtvig's distinctive theology), "folket" ["the folk"] (in which perhaps we have in part to deal with residual idiom and sentiment of the absolute monarchy - in summarising Beowulf, Grundtvig characterises Scyld Scefing and his people as "Skjold, den Landets milde Fader, og det ham kiærlig, tro hengivne danske Folk"11, but which is also a key concept in Grundtvig's definition of the community of God's people, a community not coextensive with other, established ecclesiastical, social or political groupings of "the people"), and "folkelivet" ["the life of the folk"] (where again, perhaps, we have to do with a concept of Grundtvig's own devising concerning that corporate and spiritual state of being that a congregation or community or nation can and must have, in fulfilment of its higher collective aspirations), and so on.

A truly robust scrutiny of Grundtvig's literary-critical response to Anglo-Saxon literature, as well as probing his critical discourses, would analyse in detail samples of his editing and translating not crudely to check whether his facts or his translations are simplistically correct or inaccurate, but to delineate the scope and limitations of his critical methods. For example, he endorses one of Rask's conjectured emendations to Thorkelin's text of Beowulf by appealing to the testimony of his ear. He asserts that to hear the natural correspondences and oppositions of a correctly read Anglo-Saxon alliterative line, and to register that typical balance of antithetical concepts within the poetic discourse, are for him to secure proof on a par with rational argument for the emendation needed to make the line correct: "Den herlige Giætning af Hr. Rask at der S.16, L.8 ei skal læses tha men wa i.e.: Vee, beviser sig selv ved at give, hvad der ellers fattes: Riimbogstav, Sammenhæng og den naturlige Modsætning til wel, 1.23, saa det for mig var eet at høre og bifalde den." ${ }^{.12}$

Grundtvig's could plainly be a truly sensitive and authentic response to that rich and complex art of the Anglo-Saxon poets 
which modern critics have been much concerned to bring out, whereby, at best, alliteration and metre regularly so function that the form of the line or sequence of lines is not merely a rhetorically ornate vehicle of the meaning, but actually an extension of meaning beyond the semantic sum of the words. ${ }^{13}$

On the other hand, it cannot be claimed that Grundtvig's various engagements with the text and its meaning add up to anything like an exhaustive interpretative reading of the poem, and, inevitably, Grundtvig, as pioneer in so many points of Beowulf scholarship, can seem less alert than later critics have become to some of the poet's more widely deployed strategies. For example, in his 1817 summary of Beowulf he does not appear to catch the poet's (surely deliberate) echo of distinctive terminology between Unferth's earlier ridicule of Beowulf for risking his life in an adolescent swimming dare and Unferth's later unreadiness to risk his life in the water of Grendel's mere. ${ }^{14}$ Thus he misses one of the many symmetries in the poem which later critics have seen as a structural principle - and one which is a perfectly viable alternative to those classical principles of epic structure, that testimony to true smag, the absence of which Grundtvig never quite ceased to regret in the poem. He wrote of Beowulf, for example, with a forgivable touch of chauvinism: "... it is a spiritual, only not quite artistically ordered, whole; the eye saw aright but the hand was in error; in short, one perceives here, as in Shakespeare and indeed in all English poesy, an aspiration structurally to devise colossal works of art, which can never succeed without what the Angles and English have ever lacked, that is: taste." ${ }^{15}$ It was to be largely the task of J.R.R. Tolkien and post-Tolkien critics to discern these structures more clearly and to demonstrate their narratorial, psychological and aesthetic efficacy, notwithstanding their lack of conformity with classical norms of epic poetry.

For Grundtvig, or for the nineteenth-century classicist in him, a poem aspiring to the status of epic must rest upon history, hence he found a serious problem with the apparently unhistorical Beowulf.

It is here, in Grundtvig's endeavours to do justice to the status of Beowulf as epos, in his conviction that true epic narrative must be a record of "Ordets Kamp til Seier" ["The word's struggle for 
victory" $]^{16}$, in his wider reflections upon the extensive historical writings of the Anglo-Saxons, and in his evolving concept of a universal history in which the Christian culture of the AngloSaxons held a crucial and providential position, it is here that we may observe some of the most fruitful consequences of Grundtvig's encounter with the ancient Christian literature of England, and it is here too, I think, that some of the most potentially fruitful research yet remains to be done. I shall take up this topic again shortly.

Finally, there would be some merit in attempting a reconstruction, as it were, of Grundtvig's experiencing of this remote culture through his encounter with the manuscripts in English libraries. What did he meet, what did he see, besides the specific texts which he subsequently edited, translated or paraphrased, in whole or in part? In Oxford he certainly saw Bodleian Junius 11 - a manuscript illustrated with contemporary drawings of episodes in the poems contained in the codex. In London, in the Cotton collection, were other illuminated manuscripts depicting Old and New Testament and Apocryphal topics, sometimes 'literally', sometimes in an 'exegetical' manner. They include, for example, a drawing of Christ's descent into Hell. ${ }^{17}$ May these works of the Anglo-Saxon monastic artists, still fresh and vivid to us, have fed the visual imagination of Grundtvig as did the words of the poets he was searching out from the neglect of generations? In Exeter, he encountered a codex whose organisational rationale gives the individual poems a larger, more universal context - a context more amenable and congenial, we might guess, to the mind of Grundtvig, who would have liked to be its first editor, than to the mind of Thorpe, who was in the event entrusted with that task: evidence of Grundtvig's grasp of codex as context is worth reconsidering.

But now, for the remainder of this paper I should like to look cursorily at two particular related areas of Grundtvig's response to Anglo-Saxon poetry, which lead us well into the complexity of Grundtvig the Danish Anglo-Saxonist: his perception of poetry as history and of history as the testimony of "Ordets Kamp til Seier" - the Word's struggle to victory.

In 1830, at the invitation of the London publishers Black, Young and Young, Grundtvig published in English a Prospectus 
entitled Bibliotheca Anglo-Saxonica, intended to coincide with his third successive visit to England on Anglo-Saxon business, as well as with the appearance of Rasmus Rask's Grammar of the AngloSaxon Tongue, translated into English by Benjamin Thorpe, and of other items planned, seemingly, to corner a developing market in Anglo-Saxon studies.

Here in this Prospectus Grundtvig made his proposal for publication by subscription of a series of volumes of Anglo-Saxon texts, prose and poetry, including Beowulf.

The first part of the Prospectus presents a review of the current state of neglect by Great Britain of its ancient literary treasures, and conveys Grundtvig's idea of the best case that could be made for their urgent publication. This case - which is in fact more extensively pondered in various drafts among papers in the Grundtvig Arkiv - includes the argument that: "the literary relics of this people [the Anglo-Saxons] form some of the most invaluable documents and records we possess for the Universal History of mankind." ${ }^{18}$

This absorption with the idea of a Universal History, in which England and her Anglo-Saxon Christian culture and its poets had their crucial key place and function in the whole sequential history of western Christendom, preoccupies Grundtvig over many years.

It is commonplace to recall that Grundtvig had practical grounds for bitterness towards Great Britain. The irreparable losses suffered during the British bombardment of Copenhagen in 1807 and subsequent hostilities, not only of life, property, mercantile strength and economic viability, but of treasures of the Danish cultural heritage, personal libraries like that of Thorkelin, the very edition of Beowulf itself, in advanced preparation at the printers, can still at this distance in time appal us to contemplate. But Grundtvig's synthetic view of the history of the North, wherein Anglo-Saxon England was the providential route by which civilisation, in Christian form, was transplanted from the crumbling ruins of Rome into northern Europe, to be reconstrued by the ancient English poets in a Northern voice, and to be carried forth by Anglo-Saxon missionaries out of England into Frisia and Saxony and eventually into Denmark and Iceland, was apparently above and beyond the power politics of the age of Napoleon. His 
desire to immerse himself in Anglo-Saxon antiquities, and to persuade the English to share in the great task of setting these antiquities accessibly before the publics of the northern world, was surely something other than a scholar's escapism. He was capable of using Napoleon as a model in discussion of myth or heroic theory, when it suited him. He was ultimately no romantic fugitive from present realities into a safe and remote antiquity. ${ }^{19}$ Rather, he seemed to perceive in that antiquity the identity of a common cause between England and Scandinavia transcending recent hostilities; he seemed to envisage in the prospect of collaboration over the legacy of Anglo-Saxon civilisation, a path towards future unity, lying deeper than politics, between the peoples of the high North.

Again, Grundtvig is surely not simplistically concerned with what Malone calls a desire to glorify the North, ${ }^{20}$ by recalling a noble past through its literary relics. More than this, Grundtvig seems to have been led by his Anglo-Saxon studies to believe, these relics pointed to a future whose realisation he and likeminded scholars could actually help to facilitate by publishing and translating Beowulf and the other great literary monuments of Anglo-Saxon antiquity. These ideas lie behind his prospectus of 1830, as may be elicited from the Prospectus itself, and from the various preliminary drafts which survive in the Grundtvig Arkiv. They are still active in the triumphal context of his edition of the text of Beowulf, published at last in 1861. In the introduction, composed in Old English verse, with parallel Danish paraphrase which contains the real polemic of Grundtvig's address, he creates a wonderful confection, full of allusions to the text of Beowulf, upon the title of his work, Beowulfes Beorh. The very poem itself, he says, is the monumental beorh ["barrow, gravemound"] which the dying Beowulf desired should be built over his remains, to be a landmark for the guidance of future generations of seafarers across the dark oceans. The poet has wrought a matchless artefact: "mageløst er end dit Kvad/mellem begge have" ["matchless yet your song remains betwixt the two oceans" (p. vii)]. It will be the cause for ships to carry "budskab" ["tidings"] between the peoples of "Høinorden" ["the High North" (p. ix)], he says, echoing Hrothgar's vision of a new fraternity between his nation and Beowulf's. May God grant that the English, whom he regrets 
are "nu for Norden fremmed" ["presently strangers to the North" (p.xi)], recall their ancient oneness with the other peoples of the North. Then the Phoenix - the Exeter Book is also grist to this mill! - will fly "med sin Faders brændte Been" ["with his father's cremated bones" (p. xi)] to his glorious regeneration from the ashes; and "Dan og Angul midt paa Hav/Trykke Broder-Hænder" ["Dan and Angul in mid-ocean shall shake their brother-hands" (p. xi)]. Thus Saxo's legend history will have come full circle with the reunion of Dan and Angul. And thus the Golden Age of Norse myth will be fulfilled: the golden chess-pieces of the gods - or rather, the "gamle, gyldne Ord" ["ancient, golden words"] of the old poems - will be rediscovered, and at last: "Leges Tavl, som Nornen vil,/Under grønne Linde,/Voves alt paa Lykke-Spil,/Hvori alle vinde" ["Chess is played as wills the Norn, under the green linden; all is dared in game of chance, wherein all are winners" (p. xiii)].

Such a conviction has important light to shed on the reception of Anglo-Saxon literature into the complex political and ideological setting of nineteenth-century northern Europe - and it marks, incidentally, a sharp cultural division between Grundtvig and his British colleagues, in the outcome - which, among the rest, contributes to the failure of Grundtvig's enlightened initiative in publishing his Prospectus. The English did not take well to this bid to entangle the publication of English manuscripts with a nation-by-nation-based theory of Universal History, and to some extent behind Grundtvig's back, and to some extent, perhaps, as in the case of his countryman H.C. Andersen, without his perceiving those cultural impediments which are masked in the nuances of a foreign language and in the formal niceties of an alien social intercourse, Grundtvig was edged aside when the Society of Antiquaries of London was at last provoked to tackle the task he had pioneeringly advocated. ${ }^{21}$

The manner of Grundtvig's assimilation of Old English poetry into his theory of history is well illustrated by his discussions of Beowulf. The problem of Beowulf's historicity was also a literary problem: if it was to be dignified by the title epos, it had to be based upon history, in Grundtvig's definition. ${ }^{22}$ This problem he partly resolved by that assiduous historical search which led at last to his discovery of the historic prototype of Beowulf's king and 
kinsman, Hygelac. ${ }^{23}$ And partly he resolved it by his definition of legend as symbolic history. The methodology seems positively Augustinian. Just as Augustine finds in Romulus, the fratricidal city-founder, ${ }^{24}$ so Grundtvig finds in Grendel, a reflex of Cain and a reflex of the archetypal strife between good and evil in the material and temporal universe. ${ }^{25}$ I will take this further in a moment Integral to this methodology are the concepts "Begivenhed" and "Bedrift". Just as each individual person mirrors more or less clearly the characteristics of a whole family, so each "Begivenhed", each individual event or circumstance, mirrors the great event, the "Bedrift", that is its model, the archetype in the pattern of human history: "Just as each single individual, more or less faintly and dimly, mirrors and characterises the whole stock, so also does each episode of strife and victory undeniably mirror and characterise, more or less clearly, the one great achievement in time which is accomplished within humankind. If it is perceived spiritually in the light of truth, then it [the episode] is quickened into a manifest, miniaturised image of the whole of history, and a poem which expresses such a perception we can by the same token call an Epic." ${ }^{26}$ Thus it is the epic poet's role to discern the connection or correspondence ("sammenhæng") between "Begivenhed" and "Bedrift", to perceive it spiritually, in the light of Truth, so that the episode serves as a mirror of all history: "and a poem which expresses such a perception we can by the same token call an Epic".

Grundtvig's judgement in 1817 of the aspiration to epic status of the so-called Cædmonian paraphrase (the poems in Oxford Bodleian Library Junius 11) and of Beowulf was essentially based upon his distinctive and Christian philosophy of history: their attempt at epic, he said, could not have succeeded because it would have required a historical knowledge far beyond what was then available. It "would have required an insight into the struggle between Truth and Falsehood, which is to be found just as well, though by no means just as easily, in events before as well as after Christ." ${ }^{27}$ Nonetheless, he goes on to find exactly this insight in the Beowulf-poet, who, he absolutely correctly says, sought to place those pre-Christian stories which formed the "Begivenheder" of his narrative into "a kind of relationship to Christian truth", so that "therefore the fables concerning Grendel and the Dragon 
stand as the poem's principal content, as a continuation of the Devil's and the ancient giants' strife against God. ${ }^{28}$ Thus, as early as 1817 , Grundtvig was led to discern, if only in broad terms, ${ }^{29}$ what modern criticism might say is the Beowulf-poet's chief strategy. Today, the poem is indeed widely received as being the legend-embodied exposition of a certain philosophy of history, which can fairly be called Christian and Providential, and which interprets the records of human endeavour and of divine intervention in the world as records of an ongoing battle between polarised good and evil, truth and falsehood, continuous out of the age of Cain in the Old Testament through the age of the giants and Noah's Flood and up to the present time of Beowulf's battle with Cain's offspring, and foreshadowed as continuing into the future lying beyond the present of the plot.

While many of his immediate successors were to devote themselves to taking the overtly Christian topics in Anglo-Saxon poetry and construing them as covert expressions of Germanic paganism, ${ }^{30}$ then, Grundtvig - conditioned, presumably, by his personal Christian faith, by his distinctive view of the nature of history, and by his strikingly sympathetic insight into the nature of the ancient poetry of the Germanic world - claimed for the Anglo-Saxons a capacity to reread the records of their pagan past by the light of a Christian philosophy of history, a capacity to elicit the Christian "Bedrift" from the pre-Christian "Begivenheder" of their legendary-historical inheritance: modern scholarship has only latterly begun to explore the wider implications of such a thesis for the interpretation of Anglo-Saxon literature (and of artefacts such as the Franks Casket). Grundtvig grew completely confident of his position on this matter. Writing of the historical elements in Beowulf in 1841 - when Hygelac remained, as he still remains, the only figure in the poem with anything like a claim to real historical existence - Grundtvig boldly declared: "This historical yield is now both so great and so certain that henceforth Beowulf, alongside the Edda, must always be placed in the forefront of research in Nordic antiquity and it is in this regard an inestimable treasure." 31 And again, in 1861: "Nevertheless, what gives Beowulf world-historical and general scholarly significance and importance is its integrality with the old Angles' worldhistorical life and activity as a whole, which things are still only 
indifferently illuminated and less prized, least of all in England itself; but which, for all that, are just as great and, in the eyes of the spirit, unmistakable. ${ }^{32}$

In retrospect, though the modern historian might see Grundtvig's historical philosophy as idiosyncratic and outdated even in its own day, the modern literary historian may well know his own reasons for feeling impressed to find Grundtvig, in the period around 1830, associating Anglo-Saxon literature with theories of a universal history: impressed that he perceived there universal truths - not solely of the basic mythic kind which nineteenthcentury German scholars were so clever in construing, such as 'truths' about the elements and primal forces in the natural world which are usually easy enough to elicit from early literatures - but, as we learn from his many comments on this issue, didactic truths about human destiny, human choice, the life of a society - wisdom of practical ethical value to the contemporary audience, and to all who belong to "menneske-slægten" ["humankind"] engaged in the yet-unfinished strife between truth and falsehood, within the arena of worldly space and time. For to a twentieth-century AngloSaxonist there is a familiar syndrome discernible in Grundtvig's construction of universals out of History - strikingly similar, in result, to that of the early fathers and doctors of the church, such as the two who greatly influenced Anglo-Saxon literary thought, Augustine of Hippo and Gregory the Great, and finally, but not least, Bede. These all share a Providential philosophy of history, perceiving history as a mirror of the Divine Purpose and as having a causal sequentiality which can serve as a guide to human destiny, as it moved towards the end of time and of the material world.

In so far as Grundtvig's philosophy of history was founded upon an acceptance of the Bible as history ${ }^{33}$ - that is, as a record demonstrating that the material world and the finite span of worldly time are constructs of the Godhead with which the timelessness of the divinity intersects in an incarnate God and in the witness of inspired men and women through the ages, as well as, inversely, in the record of an active force of evil struggling against good - then we may all the more readily appreciate the enthusiasm he instantly felt for the Scriptural historical poetry of Bodleian Junius 11 (which was traditionally held to contain the 
surviving corpus of the first English Christian poet Cædmon), ${ }^{34}$ or for the philosophy and didacticism of Bede's History of the English Church \& People. ${ }^{35}$

Bede, through the annals of English history, and the poet 'Cædmon', through the narratives of Scriptural history, both voice a Providential understanding of history. So too, various twentiethcentury critics would argue, does the poet of Beowulf, through the legendary-historical lays of ancient Germania. Indeed, I could say for myself that when I recognise truth in Grundtvig's assertion, quite at odds with the consensus at home and abroad in his own day and for some decades to come, that the grundtone of Beowulf is plainly religious, ${ }^{36}$ it is my sense of this underlying and underpinning Providential view of history in the poem which substantially furnishes this endorsement.

What I refer to here is the (familiar enough) view of history which was strongly prevalent through the Middle Ages, that since the Godhead has a Providential plan for the world and for humankind he created, a redemptive plan whose ultimate fulfilment is beyond this finite and temporal world and human mortality, the record of affairs in this world can be seen as the revelation of the Godhead's purposes. As the fulfilment in the New Testament of truths foreshadowed in the Old Testament archetypically shows, events in the world's history relate forwards and backwards to each other - because they are only reflexes of the same abiding truth. Thus Bede sees parallels between the early history of the Anglo-Saxons and the history of the Chosen People of the Old Testament, which are not accidental analogies, but parallel manifestations of one abiding truth. And thus the poet of the Old English poem Exodus sees prefigured in the pillar of fire and the Crossing of the Red Sea the saving power of the Cross and the Sacrament of Baptism: his poem, therefore, is not a mere paraphrase of the Old Testament narrative, but an exegetical work bringing out these Providential correspondences in history. So too the Beowulf poet proceeds even within the terms of his 'secular' and Germanic-legendary narrative. ${ }^{37}$

Many critics, therefore, acknowledge that the Beowulf poet is speaking of universal truths of human history, as perceived by the poet within a Christian-Providential philosophy of history. Grundtvig saw this too, in part at least, long ahead of other, 
somewhat supercilious, nineteenth and twentieth-century commentators, whom J.R.R. Tolkien eventually took on in 1936, archly equating in his title the critics and the monsters.

This typical historicity of Beowulf was, then, an issue of great and particular concern to Grundtvig; and all this, I am sure, merits fresh and fuller investigation and evaluation (to a great extent on the basis of Professor Haarder's work), for the sake of Anglo-Saxon no less than for Grundtvig studies.

Finally, the second and surely the far more complex and significant aspect of Grundtvig's response to his encounter with Anglo-Saxon literature: the colouring it drew from, and the contribution it made to Grundtvig's evolving concept of Ordet, the Word. In this response the literary historian may find a remarkable statement of the view that poetry is, or may be, divinely inspired - a view, needless to observe, which Bede was ready to endorse in narrating the gift of divine grace by which Cædmon was transformed into the first Christian poet of the English. ${ }^{38}$ But here too the literary historian encounters one among various terms which demand very special glossing by twentieth-century, and especially by non-Danish readers of Grundtvig.

One may think, for example, that one knows exactly what Grundtvig means when he is discussing the ending of Beowulf and says that in this forty-third song "We glimpse the funeral pyre burning, the burial-mound rising over the hero's ashes and antiquity's gold, and the bard with tear-filled eyes moving his lips in a lamentation upon the intrepid one, but that is virtually all, for it is as though the smoke enveloped the figures and weeping choked the word. ${ }^{39}$ In a literal, narrative sense, smoke shrouded their shapes; weeping choked "Ordet" - their speech, or song. But Grundtvig goes on to suggest, more broadly than this, an analogy between this narrative scene and the modern status of the poem itself as a monument of antiquity: like an ancient golden harp plucked from the pyre, with strings burst and tuning-pegs melted, the poem cannot voice for us the full and original tone and meaning of its "Ord". "Ordet", then, is Grundtvig's word for voices within the poem, it is his word for the voice of the poem itself; and it is, as his discussions of Cædmon and Anglo-Saxon religious 
poetry more widely show, the word for the voice of noble poesy as a whole, speaking for and to its parent culture.

But more, still, than this - this same "Ord" has to do with the spiritual life and its expression, not merely in this poem, not only in all poesy, but in the whole record of human affairs that comprises history: "The Word is, as Scripture teaches, and as we can now understand, the highest and the deepest expression of Life's revelation, and the whole of history must be perceived as the Word's struggle for victory. ${ }^{40}$

"Ordet", indeed, in its highest semantic application, is Christ, whose incarnate life furnishes the stuff, Grundtvig would say, of the only true Epic that may be elicited from History: "The life of Christ on earth, the Word's pilgrimage in the flesh ... is an event which not only mirrors but comprises truth's struggle and its victory, and seems, when spiritually perceived, necessarily to result in the sole true epic which it is possible to create in history. ${ }^{\text {"41 }}$

"Ordet", then, is also "Sandhed" ["truth"]; and these ancient poems, mirroring (if imperfectly) history itself, properly portray the world as the battle-ground of the "Kamp mellem Sandhed og Løgn" ["battle between Truth and Falsehood"]. ${ }^{42}$

Grundtvig thus seems to argue an integral connection between the truth he finds voiced through ancient poetry of the North, and that concept of "det levende Ord" ["the living Word"] he developed as a central conviction in his definition of the congregation of God's people.

This viewpoint apparently interacted dynamically with what Grundtvig found in Anglo-Saxon poetry, especially in the miraculously-inspired testament of Cædmon, and in Beowulf, over these formative years. In the strange poem Ragna-Rok, Grundtvig includes with Norne-Giæst in his cast-list the Spirits of Luther and of Cædmon. Luther he presents as a latter-day Beowulf, fighting fire and venom to disable "Romas Trold" ["the troll, Rome"]: "Ja, feig fra Kampens Bulder/Alt fra sin Arm og Skulder/Som Grendel flygted han" ["Yes, craven from the battle's thunder, and from his arm and shoulder withal, he, like Grendel, fled"]. ${ }^{43}$ This equation one may also inspect from the other end on - and conclude that Grundtvig had discovered in Beowulf a legendary archetype of the world's great struggle between Truth and Lies, of "Ordets Kamp til Seier", of which Luther's struggle 
is a latter-day historical reflex. The poet has expressed symbolically, through legend, a universal truth about the human condition which is also manifest within history, and, better still, within the very same cultural lineage within the early and latterday cultural history of the North: and this, in turn, adds up to a certain distinctive philosophical viewpoint held by Grundtvig upon the nature of historical testimony itself, and the use to which it may legitimately be put. It is, I would again add, a viewpoint which Bede might well have understood, and one to which (I myself believe) the poet of Beowulf himself in his own terms demonstrably subscribed. And Grundtvig himself in fact elaborates suggestions along these lines elsewhere.

Cædmon's appearance in Ragna-Rok ${ }^{44}$ is equally remarkable and revealing of Grundtvig's dynamic response to what his preconditioned mind found at his encounter with Anglo-Saxon poetry. Here Cædmon materialises as the embodiment of Luther's invocation of a hand and a harp that will sing praise to God and be a "Redskab for Bibelens hellige Aand" (p.339) ["an instrument of the Bible's holy spirit"], Cædmon's Spirit (speaking in Grundtvig's best imitation of Anglo-Saxon half-lines) says that he dreamed and saw king David who gave his harp into Cædmon's hands. Cædmon taught his ear and tuned his tongue by the Scriptures, while his gaze discovered there "Billeder høie" (p. 340) ["exalted images"]. Boldly, Grundtvig has Cædmon sing the opening of the Old English Genesis: "Us is riht micel/Dhæt ve rodera-veard/Vereda vuldor-cyning/Vordum herigen!" (pp. 34041. The spelling conventions are Grundtvig's) ["Ours is a great duty: that we should praise in words the glory-king of hosts"]. "Toner som disse", says Cædmon (and, with him, the polemicist Grundtvig), "Tør jeg vel haabe,/Sank ei i Tidens/Skummende Bølger" (p. 341) ["Notes such as these, I well dare hope, would never sink in the foaming waves of time"].

Beowulf too Grundtvig's Cædmon quotes, as though indeed he were its composer - but here presumably Grundtvig is letting Cædmon stand for all Anglo-Saxon poets collectively. "Jeg Øre og laande/Til Oldtidens Sagn,/I Krands jeg dem fletted/Med Konst jeg dem bandt" (p. 341) ["I heard and drew from stories of yore, I wove them in garlands, with artistry bound them"] and he recites the opening of Beowulf. "Saa jeg paa Harpen/Hævede Sandsagn, 
/Adled til Epos/Oldtidens Digt,/Stridige Stykker/Snildt jeg forbandt:/Yndig blev Sandhed/Og Æmter sansynligt" (pp. 341-42) ["Thus to the harp I exalted true legend, ennobled to epic the fiction of yore, contrary pieces I artfully joined: truth became beauty and fable good sense"].

Cædmon says, then, that he has taken true legend, or, perhaps, legendary truth, and ennobled it to epic, so that truth has become beauty and fable good sense. Elsewhere, Grundtvig is more reserved about according Beowulf the formal label "Epos", but even in withholding it he nonetheless reaffirms his tenet, that, articulated in the legendary circumstances even of unhistorical episodes, there may be found the statement of "Sandhed", the Truth, about the human condition: "The Lie's hostile disposition towards Truth reveals itself, in fact, partly in its assault upon Truth's realm [Grendel's attack on Heorot], partly in the concealment it imposes upon Truth's lawful property [the dragon's annexation of the buried treasure-hoard] ... partly in history, partly in nature ... Grendel stands as time's, the dragon as nature's, evil spirit; and therefore stronger authority could well be adduced [here] than in the nordic myth of Ragnarok, that it will in truth cost man his mortal life to destroy The Lie in nature. ${ }^{145}$

The "levende ord", history as the record of "Ordets Kamp til Seier", Anglo-Saxon literature as testimony to such a perception of this worldly experience in ancient days of the High North, these are topics with which Grundtvig was already deeply engaged in 1817. Indeed, the very context of Grundtvig's pioneering discussion of Beowulf - namely, the series of Danne-Virke volumes of 1817 - makes clear beyond all question the theological and philosophical context in Grundtvig's thought at that time, into which his encounter with Anglo-Saxon culture fed ideas, and out of which his interpretation of Beowulf drew much of its ideological content. In these volumes, as Dr. Helge Grell's recent study has well elucidated, ${ }^{46}$ Grundtvig was deeply preoccupied with the relationship of the Word of the Creator God which brought all things into being, and human speech and especially the artistic voice of poesy which embodies the revelation of the Creator's primal word.

The Beowulf-poet shared the same perception, I feel sure: why else, if not pointedly to echo the divine Fiat of the Creator's 
word, does he choose to have a song of the earth's creation sung by the poet in the new-built hall Heorot ${ }^{47}$ - whose building is thus immediately seen to mirror the Creator's primal act of creation? Why does he name the people's adornment of Heorot with human artefacts and the Creator's beautification of the earth with branch and leaf in the same word? Because the primal creativity of God may be emulated, innocently albeit imperfectly, by God's creatures; and then it is the poet's inspired task to articulate the primal truth bodied forth, however imperfectly, in this emulation.

Here again, Grundtvig, if idiosyncratic in his own century, appears close to the mentality and ideological makeup of the Anglo-Saxon poet.

In Fascikel 363.1, p. II, in the Grundtvig Arkiv, containing Grundtvig's notes towards his Prospectus, is a draft document in Danish of which Steen Johansen says (in the Registrant): "Its heading refers to the history of mankind, and the content is partly an outburst against an arid scientific spirit, partly an exposition of Grundtvig's special notion of the living word, which in fact dawned upon him in earnest during his second visit to England, 1830." 48 It is clear that Grundtvig's own ideas in these areas, and ideas he was gleaning from his encounter with Anglo-Saxon literature well before his first visit to England in 1829, were working in a dynamic mutuality already by 1817 . They were to develop, and to be modified, but not to be abandoned, through the remainder of his long career in Anglo-Saxon studies. Their full nature, their status as insight into the Anglo-Saxon mind, and their bearing upon Grundtvig's own intellectual development, merit the fresh examination this project promises.

I must stop. When I was preparing this paper in the British Library in London, reading through a range of the central texts in the history of Grundtvig-as-Anglo-Saxonist, I saved up for myself, in chronological sequence, consultation of Grundtvig's edition of Beowulf which is in many respects the triumphant culmination of his fifty-odd years' engagement in sometimes bitter and often frustrating academic combat. When the British Library 
copy was delivered into my hands, it turned out to be the very copy Grundtvig presented to the British Museum (as it then was) in 1861. Inside, in his own hand, was Grundtvig's inscription: "Til Det Brittiske Museum, Bjovulfs-Drapens Arnested i taknemmeligt Minde fra 1829-31 fra N.F.S. Grundtvig. Kiøbinghavn 1861, Nov. 4" ["To the British Museum, hearth and home of the Beowulfpoem, in grateful remembrance of $1829-31$, from N.F.S. Grundtvig. Copenhagen 1861, November 4"].

I felt then just a moment of intimacy with the old warriorscholar Grundtvig: what an economical hint of mild malice and justified pride lay within that generous inscription. I rejoice, through these proceedings, in coming closer still to this remarkable Dane.

Notes

1 K. Malone, 'Grundtvig as Beowulf Critic'. Review of English Studies 17 (1941), p. 129.

See below, note 4 .

F. Cooley, 'Early Danish Criticism of Beowulf', in English Literary History 7 (1940), p. 54.

A. Haarder, 'Et gammel indlæg i en ny debat: Grundtvigs vurdering af Beowulf som kunstværk'. Grundtvig Studier (1965), pp. 33-34: "Naar Grundtvig har beskæftiget sig med Beowulf har han været videnskabsmand, litteraturkritiker, mytefortolker" - and one might add one or two more labels to Professor Haarder's list - "uden at det er muligt at konstatere, at i dette eller hint værk er han udelukkende det ene eller det andet ... En behandling af emnet 'Grundtvig som Beowulf-kritiker' synes derfor at maatte sprænge en streng rubricering af Grundtvig-materialet. 
Most of this material is gathered in the Grundtvig-Arkiv in the Royal Library, Copenhagen, and catalogued in $\mathrm{H}$. Høirup and H. Topsøe-Jensen (ed.), Registrant over N.F.S. Grundtvig's Papirer; Udgivet af Grundtvig Selskabet af 8. September 1947 og Det Danske Sprog- og Litteraturselskab, 30 volumes (Copenhagen, 1957 - 64).

Among more recent evaluations are: F. Cooley, 'Early Danish Criticism of Beowulf. English Literary History 7 (1940), pp. 45-67. K. Malone, 'Grundtvig as Beowulf Critic'. Review of English Studies 17, no. 66 (1941), pp. 129-38; F. Cooley, 'Contemporary Reaction to the Identification of Hygelac', in T.A. Kirby, and H.B. Woolf (ed.), Philologica: The Malone Anniversary Studies. Baltimore, 1949; A. Haarder, 'Et gammelt indlæg i en ny debat: Grundtvigs vurdering af Beowulf som kunstværk', in Grundtvig Studier (1965), pp. 7-36; A. Haarder, 'Syv Beowulf-anmeldere', in Grundtvig Studier (1968), pp. 6575 (incorporated as ch. 1 in A. Haarder, Beowulf: The Appeal of a Poem, Copenhagen, 1975; Malone's evaluation of Grundtvig is usefully discussed by Haarder in pp. 63-65 and 73ff); E.G. Stanley, 'The scholarly recovery of the significance of Anglo-Saxon records in prose and verse: a new bibliography' in Anglo-Saxon England 9 (1981), pp. 223-262, which contains further valuable bibliographical references to evaluations of Grundtvig's importance in this field; articles in C.T. Berkhout and M. McC. Gatch (ed.), Anglo-Saxon scholarhip: The first three centuries (Boston, 1982); A. Haarder, 'Grundtvig and the Old Norse Cultural Heritage' in C. Thodberg and A.P. Thyssen (ed.), and E. Broadbridge (tr.), N.F.S. Grundtvig: Tradition and Renewal (Copenhagen, 1983), pp. 72-86; and the statistical tabulations of editorial readings proposed and accepted in the Beowulf text, in B. Kelley, 'The formative stages of Beowulf textual scholarship' in Anglo-Saxon England 11 (1983), pp. 24774, and Anglo-Saxon England 12 (1983), pp. 239-76. 
Grundtvig Arkivet, Fascikel 328, 17; Registrant, vol. XV. Percy himself, of course, represents fairly accurately the perception England had of Danish and Scandinavian antiquities in Grundtvig's day. His image of Denmark and its early culture he had chiefly acquired from Paul Henri Mallet's Introduction à l'Histoire du Dannemarc (1755), translated by Percy in 1770 in Northern Antiquities.

Bibliotheca Anglo-Saxonica (London, 1830), p. 6 and p. 10.

The Anglo-Saxon Poems of Beowulf, the Scôp or Gleeman's Tale and the Fight at Finnesburg (Oxford, 1855). Thorpe had resided for a period in Denmark, returning to England in 1830.

Bjowulfs Drape (1820), p. XXI: "Angel-Sachsisk havde jeg aldrig læst, da Bjowulfs Drapen [Thorkelin's edition of the poem] udkom, men begeistret for at kjende den, og temmelig fortroelig med Edda, faldt det mig ikke vanskeligt, snart at opdage en Deel af Udgavens Brøst ..." ["Anglo-Saxon I had never read before Bjowulfs Drapen came out, but, keen to get to know it, and being fairly familiar with the Edda, it did not prove difficult for me soon to discover a number of the edition's shortcomings..."].

For example, in summarising Beowulf (Danne-Virke II, 1817, p. 219. Grundtvig characterises Scyld Scefing and his people as "Skjold, den Landets milde Fader, og det ham kiærlig, tro hengivne danske Folk" ["Scyld, gracious Father of the land, and the Danish folk, loving towards him, and faithfully devoted."].

Danne-Virke II (1817), p. 222: "The excellent conjecture of Hr. Rask that on p. 16, 1. 18 there should be read not tha but $w a$, that is: 'woe', commends itself by supplying what is otherwise lacking: alliteration, cohesion and the natural apposition with wel, 1.23 , so that for me it was 
one and the same thing to hear it and to endorse it." Beowulf 183 and 186 in modern editions. The manuscript reading (fol. 134r) does indeed support the emendation: Thorkelin seems to have made the easy error of reading wynn as thorn.

It must be admitted however that in his prefatory poems to Bjowulfs Drape (1820) and Bjowulfes Beorh (1861) both pastiches of half-lines from Beowulf and half-lines of his own composition - Grundtvig shows, as a composer of Anglo-Saxon poetry, more panache than authenticity.

Danne-Virke II (1817), p. 230-31; 'Beowulf 508-510 and 1468-70.

Danne-Virke II (1817), p. 271: "det er et aandigt, kun ikke ret konstmæssig ordnet, Heelt, Øiet saae ret, men Haanden tog feil, kort sagt, man sporer her, som hos Shakspear, og vel i al engelsk Poesie, en Bestræbelse efter planmæssig at frembringe colossale Konst-Værker, som aldrig kan lykkes uden, hvad Angler og Engellænder altid have savnet, det er: Smag." See also A. Haarder, 'Et gammelt indlæg $\mathrm{i}$ en ny debat: Grundtvig's vurdering af Beowulf som kunstværk', Grundtvig Studier (1965), p. 22: "...det er først og fremmest digtets struktur, Grundtvig ikke kan forlige sig med: anvendelsen af 1) episoder 2) uhyrekamper (digtets to dele) inden for Beowulf-digtets rammer" ["... it is first and foremost the poem's structure that Grundtvig cannot reconcile himself with: the use of 1) digressions 2) the monster-fights (the poem's two sections) within the Beowulf-poem's framework"]; also Professor Haarder's discussion of Grundtvig's judgement of Beowulf in Beowulf: The Appeal of a Poem (Aarhus, 1975 ), especially pp. $68 \mathrm{ff}$.

Danne-Virke II (1817), p. 273. See further below, note 40. 
London British Library MS Cotton Tiberius C.vi (The Cotton Psalter), fol. 14. As is well known, Grundtvig acknowledges the episode of Christ's descent into Hell in the Anglo-Saxon poem now known as Christ and Satan in Oxford Bodleian Library MS Junius 11 as a source of his own poem "I Kveld blev der banket paa Helvedes Port", published as Hymn 243 in Sang-Varket til den danske Kirke (1837).

Drafts of the Prospectus are in Fascikel 363, 1-13 (Registrant, vol. XVI). This, and Grundtvig's suggestion that the Anglo-Saxons "have exercised a far greater influence over the modern civilized world, than even their illustrious descendants", are in Bibliotheca Anglo-Saxonica (London, 1830), p. 3.

Though note the opinion of F. Cooley, 'Early Danish Criticism of Beowulf', in English Literary History 7 (1940), pp. 45-67: "In his long life of activity - he was poet, preacher, theologian, statesman, educator, reformer, philologian - his work on Beowulf filled odd moments, and not all of them. It seemed to be his solace for the disappointments of ecclesiastical life. Before 1815 , when he first spent a great deal of time on the poem, and before 1829, when he undertook the first of several trips to England to study Old English literature, he was engaged in religious and political struggles from which he felt it best for the time to withdraw" (p. 54).

K. Malone, 'Grundtvig as Beowulf Critic', Review of English Studies 17, no. 66 (1941), pp. 129-38: "It was the poet's intention to glorify the North; more specially, to glorify a particular period in the history of the North" ( $p$. 136).

English correspondence and diaries (of Sir Frederick Madden and other figures associated with the Antiquaries) reveal the other side of Grundtvig's various reports and accounts of the activities around 1830 . See 
H. Toldberg, "Grundtvig og de engelske antikvarer" in Orbis Litterarum, Tom. 5, Fasc. $3 / 4$ (1947).

He discusses the issue in Danne-Virke II (1817), concluding (p. 273) that, since truth to history is so essential to epic, the only true epic is the one embracing the whole of history - of history, that is, perceived in the light of truth: "Nu see vi da vel, at kun den hele Historie, beskuet i Sandheds Lys, udgiør og udtrykker det sande Epos og Heltedigt" ["Now we surely see that only the whole of history, perceived in the light of Truth, comprises and expresses the true epic and heroic poem"].

Registrant, Fasc. 328, 9-11: Historical extracts relating to Anglo-Saxon literature copied by Grundtvig in this document include passages from Bouquet's text of Gregory of Tours' History of the Franks in which Grundtvig found the reference to Chocilaicus, prototype of Hygelac. For Grundtvig, of course, the Hygelac-Chocilaicus identification was not merely a historical clue to the dating of the poem's genesis, but rather a notable vindication of the status of the poem in terms of his concept of what constituted an epic.

Augustine, The City of God, Book XV, chapter 5. See also below, note 37 .

See for example, Danne-Virke (1817), p. 278, cited in note 28 below.

Danne-Virke II (1817), p. 273: "... ligesom hvert enkelt Menneske, kun mere og mindre mat og dunkelt, afbilder og betegner Slægten, saaledes afbilder og betegner unægtelig enhver Begivenhed med Kamp og Seier, kun mere og mindre tydelig, den ene, store Bedrift i Tiden, som fuldføres ved Menneske-Slægten; beskues den aandig i Sandheds Lys, da oplives den til et synligt, sammentrængt Billede af hele Historien, og et Digt, som udtrykker en saadan Beskuelse, kan vi med samme Føie 
kalde et Epos" ["Just as each single individual, more or less faintly and dimly, mirrors and characterises the whole stock, so also does each episode of strife and victory undeniably mirror and characterise, more or less clearly, the one great achievement in time which is accomplished within humankind. If it is perceived spiritually in the light of truth, then it [the episode] is quickened into a manifest, miniaturised image of the whole of history, and a poem which expresses such a perception we can by the same token call an Epic"]. This view is partly discussed in $\mathrm{K}$. Malone, 'Grundtvig's philosophy of history' in Journal of the History of Ideas, vol. 1 (1940), pp. 281298; and it is extensively and discriminatingly discussed by A. Haarder in Beowulf: The Appeal of a Poem (Aarhus, 1975), pp. 68ff. See also W. Michelsen, 'Om Grundtvigs historiesyn', Grundtvig Studier (1965), pp. 49-54, for a reassertion of the view that "Grundtvig's view of history was biblical" (English summary, pp. 44-5).

Danne-Virke II (1817), p. 278: "... krævede en Indsigt i den Kamp mellem Sandhed og Løgn, der ligesaa vel, men ingenlunde ligesaa let, findes i Begivenhederne før som efter Christus." I take it that by "before" and "after" Christ, Grundtvig is making reference not strictly to the periods of world history before and after the Incarnation, but also to the periods before and after a converted people's reception of Christ.

Danne-Virke II (1817), p. 278: "et Slags Forhold til den christelige Sandhed... derfor staae Eventyrene om Grendel og Dragen som Digtets Hoved-Indhold, som en Fortsættelse af Djævelens og de gamle Giganters Kamp imod Gud."

Andreas Haarder, in Beowulf: The Appeal of a Poem (Aarhus, 1975), scrupulously discriminates between Grundtvig's position and that of J.R.R. Tolkien, in 'Beowulf: the monsters and the critics'. Proceedings of the British Academy XXII (1936) and persuasively insists that 
even when Grundtvig accords the poem its value as a whole, "we are not anywhere near the holistic interpretation advanced by Tolkien" (p. 75).

See for example E.G. Stanley, The Search for AngloSaxon Pagan (Totowa and Cambridge, 1975) and A. Haarder, Beowulf The Appeal of a Poem (Aarhus, 1975).

'Bjovulfs-Drape eller det Oldnordiske Heltedigt', in Brage og Idun 4de Bind, 2det Hæfte (September, 1841), p. 510: "Dette historiske Udbytte er nu baade saa stort og saa sikkert, at Bjovulfs-Drapen herefter ved Siden af Edda altid maa stilles i Spidsen ved den Nordiske Oldgranskning, og det er i denne Henseende en ubetalelig skat."

Beowulfes Beorh (1861), p. xxiv: "Hvad der imidlertid giver Bjovulfs-Drapen verdenshistorisk og almen-videnskabelig Betydning og Vigtighed, det er dens Sammenhæng med de gamle Anglers verdenshistoriske Liv og Virksomhed i det Hele, der vel endnu kun er maadelig oplyst og mindre skattet, allermindst i Engeland selv, men er derfor dog lige store og for Aandens Øine umiskiendelige."

See, for example, William Michelsen, 'Om Grundtvigs Historiesyn', Grundtvig Studier (1965), pp. 49-54 where he reasserts his view "that Grundtvig's view of history was biblical ... In my opinion, it was Luther who directed Grundtvig away from 'gnosticism' by teaching him to regard the Bible as historical truth ... Grundtvig the historian neither can nor will conceal his Christian faith." (English summary, pp. 114-15),

As early as 1817, in Danne-Virke II, Grundtvig was writing enthusiastically of "den saakaldte Cædmonske Paraphras" [the so-called Cædmonian paraphrase] of which we have only part, the poet's original purpose being to cover the whole Scriptural history through to the Resurrection: "Ingen kan nægte at det var et colossalsk episk syn, som begeistrede den gamle Digter" 
[None can deny that it was a colossal epic vision which enthralled the old poet], but the work never came to form "noget beskuelig Heelt" [any discernible whole] ( $\mathrm{p}$. 277).

Grundtvig was also interested in the ninth-century 'Alfredian' translation of Bede's History into Old English.Various extracts from the Alfredian Bede survive among papers in the Grundtvig Arkiv, apparently as preparatory material for a Universal History.

Bjowulfs Drape (1820), Indledning, p. LII: "Føier man hertil Digtets Ærbarhed, dets Inderlighed mangensteds, og dets religiøse Grundtone, da maa man vel bekjende, det er i alle Maader et udmærket Oldtids-Minde." ["If one adds to this the poem's decorum, its fervency in many places, and its underlying religious tone, then one must surely acknowledge that it is in all respects an outstanding monument of antiquity"].

Conspicuous are the poet's devices of giving Grendel ancestry reaching back to Cain, and of linking, for example through the inscription discovered on the hilt of the sword which Beowulf finds on the wall of Grendel's lair and uses to kill Grendel's mother, the strife of the Grendels against Heorot with the strife of the antedeluvian giants against God. The devices have a methodological affinity with Augustine's procedures in The City of God, where he perceives a replication of Cain's violence and city-founding in the legend-history of Romulus, Remus and the founding of Rome: see above, note 24.

History of the English Church and People. Book IV, chapter 24. Grundtvig, however, conspicuously places emphasis not on he mystical aspect of Cædmon's creativity but on the compositional craftsmanship of an autonomous poet; thus, while admiring the "colossalsk 
episk Syn" ["colossal epic vision"] of the poet, he can chide him for a failure in "smag" ["taste"].

Danne-Virke II (1817), pp. 270-271: "skimte vi Baalet flamme, Høien hæve sig over Heltens Aske og Oldtids Guld, og Skjalde med taarfulde Øine, bevæge Læberne til Klagesang over den Bolde, men det er hardtad ogsaa Alt, thi det er som Røgen indhyllede Skikkelserne, og Graaden kvalde Ordet."

Danne-Virke II (1817), p. 273: "Ordet er, som Skriften lærer, og som vi nu kan fatte, det høieste og dybeste Udtryk for Livets Aabenbarelse, og den hele Historie maa betragtes som Ordets Kamp til Seier." There is a valuable discussion of this distinctive Grundtvigian thesis in A. Haarder, Beowulf: The Appeal of a Poem (Aarhus, 1975), pp. 68ff.

Danne-Virke II (1817), p. 275: "Christi Liv paa Jorden, Ordets Vandring i Kiød ... er en Begivenhed, der ikke blot afbilder men indeholder Sandheds Kamp og Seier, og som synes, aandig beskuet, at maatte frembringe det eneste sande Epos, der i Historien lader sig skabe."

Danne-Virke II (1817), p. 278.

Danne-Virke III (1817), p. 327.

Danne-Virke III (1817), pp. 301ff.

Danne-Virke II 81817), p. 279: "Løgnens fiendtlige Forhold mod Sandheden viser sig nemlig: deels i dens Anfald paa Sandhedens Rige, deels i det Dølgsmaal den lægger paa Sandhedens lovlige Eiendom ... deels i Historien, og deels i Naturen ... Grendel staaer som Tidens, Dragen som Naturens onde Aand, og at det virkelig vil koste Mennesket sit jordiske Liv at dræbe Løgnen i Naturen ... derfor kunde vel anføres stærkere Hjemmel end den nordiske Mythe om Ragna-Roke." 
Grundtvig repeats this idea in 1820 in his Introduction (pp. L-LI) to Bjowulfs Drape: "Jeg finder end videre, at Bjowulfs eventyrlige Kampe betegner de to store Afdelinger af Menneske-Kampen mod hin Mørkets Magt, som deels yttrer sig i voldsomt Anfald paa Kæmpe-Livet, deels i Rugen over de Vaaben og Skatte som høre til dets Fortsættelse, eller med andre Ord: deels i Historien og deels i Naturen. Allerede Dette giver Digtet en vis Grad af poetisk Sandhed, som i mine $\varnothing_{\text {jne hæver sig til }}$ en sand og herlig historisk Beskuelse..." ["I find furthermore that Beowulf's fabulous fights represent the two great divisions of humankind's fight against the power of darkness, which evinces itself partly in violent assault upon the warrior-life, partly in brooding upon those weapons and treasures which pertain to its [the warriorlife's] continuation, or in other words: partly in history and partly in nature. This already gives the poem a certain degree of poetic truth, which in my eyes elevates itself to a true and glorious historical prospect"]. However, it is the fusion of history with fable which, he says, deprives the poem of "indvortes Eenhed" ["inner unity"].

H. Grell, Skaberordet og billedordet: Studier over Grundtvigs teologi om ordet. Studier udgivet af GrundtvigSelskabet XVII (Copenhagen, 1980). See especially pp. 66-69. I am grateful to Dr. Grell for his communication.

Beowulf, 67-79 and 89-98.

Steen Johansen, Registrant, vol XVI: "Dens overskrift taler jo Menneskehistorien, og indholdet er dels et udfald mod død videnskabelighed, dels en fremstilling af Grundtvig's særlige idé om det levende ord, en idé, der netop for alvor gik op for ham under hans anden Englandsrejse, 1830." 